\title{
The Aromatic-Medicinal Plant Taxa of pure Scots pine stands in Sürmene - Camburnu (Trabzon)
}

\author{
Arzu ERGÜL BOZKURT *1, Salih TERZİĞLU ${ }^{2}$ \\ ${ }^{1}$ Artvin Çoruh University, Faculty of Forestry, Artvin, Turkey \\ ${ }^{2}$ Karadeniz Technical University, Faculty of Forestry, Trabzon, Turkey
}

Received: 04 May 2017 - Revised: 21 September 2017 - Accepted: 03 November 2017

\begin{abstract}
Forests not only produce wood raw material ecosystems, but also that have rich medicinal and aromatic plants. In addition to this situation, forests have been produced many goods and services. Regulation of protectionutilization balance with wood and non-wood herbal products is very important to these ecosystems. In order to ensure sustainable utilization of forest ecosystems, first of all, it is necessary to identify the natural resource components in these ecosystems. In this study, medicinal-aromatic plants of natural Scots pine (Pinus sylvestris L.) stands, which are a sensitive ecosystem, were investigated in 2013-2014. Pinus sylvestris has special ecological conditions in Sürmene-Çamburnu (Trabzon) region because in this region Pinus sylvestris is descending down to the beach. In the study, 81 (77\%) out of 105 vascular plant taxa were found to have medicinal-aromatic potential. The parts of the identified plant taxa used for different medical and aromatic purposes are explained in detail. In addition, recommendations were made about regulation of utilization in sensitive ecosystems.
\end{abstract}

Keywords: Pinewood, medicinal-aromatic plant, flora

\section{INTRODUCTION}

Forests are the ecosystems that produce not only wood raw material but as well non-wood forest products. In the one hand forest ecosystem serves the products which meet the needs of people directly or indirectly, on the other hand it contains the rich plant diversity. One of the well-known of products of forests are medicinal and aromatic plants. Briefly, forests have produced many goods and services. The continuity of forest functions such as conserving biodiversity and utilization are important. Conservation and utilization equilibrium with wood and non-wood plant products is very important to these ecosystems. In order to ensure sustainable utilization of forest ecosystems, first of all, it is necessary to identify the natural resource components in their habitats. Ethnobotanical studies have been tried to determine these potentials. Ethnobotanical science was born from the relationships between people and plants [1]. People have been using wild plants since 50,000 years in Anatolia [2]. Because of its rich cultural and biological diversity, Turkey is an important center for ethnobotanical researches

*Corresponding Author E-mail: ergul_arzu@yahoo.com

ISSN: 2148-6905 online /(C) 2017

DOI: $10.21448 /$ ijsm. 377774 
[3]. Local people in Anatolia have benefited from medicinal and aromatic plants for many years. But these uses are not scientifically well supported. From this point of view, multidisciplinary (ie, botanist, chemist, medical experts) studies on the aromatic-medicinal plants should be conducted.

Depending on the health problem of processed food, natural products are getting worth to attention day by day. Natural forest ecosystems of Anatolia are rich in such kind of native vascular plant products including ethnomed,cinal plant taxa. In Turkey, these plants have not been used enough because of lack of inventory data of these taxa.

In this study, medicinal-aromatic plants of natural Scots pine (Pinus sylvestris L.) stands, which are a sensitive ecosystem in Sürmene-Çamburnu (Trabzon-Turkey), were investigated. Pinus sylvestris has special ecological conditions in the study area where starts its natural distribution from Sea level. The parts of identified vascular plant taxa which have been used for the medical-aromatic purposes are explained in detail. In addition, recommendations were made about regulation of utilization in sensitive ecosystems.

\section{MATERIAL and METHODS}

The floristic structure of the research area was investigated between February to November in the years 2013 and 2014. Within the scope of the study, plants from the research area were collected from the study area, identified and kept at the herbarium KATO (Herbarium of Karadeniz Technical University Faculty of Forestry). The plant taxa which particularly have medicinal and aromatic significance were determined. As a result of detailed literature study, the listed taxa were found out that they worth to use for medicinal-aromatic purposes.

\section{RESULTS and DISCUSSIONS}

In the present study, 81 (77\%) out of 105 taxa were found as medicinal and aromatic vascular plants. They were listed in Table 1 together with their families, used parts, usages and references.

Table 1. Medicinal and aromatic vascular plant taxa together with their families, used parts, usages and references.

\begin{tabular}{|c|c|c|c|c|}
\hline Family & Plant Taxa & Used part(s) & Usage & Ref. \\
\hline Araliaceae & Hedera helix & Leaves, berries & $\begin{array}{l}\text { The homeopathic preparations are } \\
\text { indicated in diseases of the respiratory } \\
\text { tract, gastrointestinal tract, rheumatic } \\
\text { diseases and hyperthyroidism. } \\
\text { Hedera leaves are also used in gout, } \\
\text { rheumatism and externally against } \\
\text { parasites }\end{array}$ & $\begin{array}{r}{[4][5][6]} \\
{[7]}\end{array}$ \\
\hline Asteraceae & Centaurea jacea & $\begin{array}{l}\text { Leaves, } \\
\text { flowers, body }\end{array}$ & $\begin{array}{l}\text { Folk medicinal use to treat abcesses, } \\
\text { hemorrhoids, peptic ulcers and the } \\
\text { common cold }\end{array}$ & [8] [9] \\
\hline Asteraceae & $\begin{array}{l}\text { Eupatorium } \\
\text { cannabinum }\end{array}$ & Aerial parts & $\begin{array}{l}\text { Ethanolic extract against colon cancer } \\
\text { cells }\end{array}$ & [10] \\
\hline Asteraceae & $\begin{array}{l}\text { Lapsana communis } \\
\text { subsp. grandiflora }\end{array}$ & $\begin{array}{l}\text { Young leaves, } \\
\text { shoots }\end{array}$ & Having a calming and antiseptic effect & {$[11]$} \\
\hline Asteraceae & $\begin{array}{l}\text { Taraxacum } \\
\text { stevenii }\end{array}$ & Whole plant & Eye diseases & [12] \\
\hline Asteraceae & $\begin{array}{l}\text { Taraxacum } \\
\text { scaturiginosum }\end{array}$ & $\begin{array}{l}\text { Capitulum, } \\
\text { stem leaf }\end{array}$ & $\begin{array}{l}\text { Anti- inflammatory, } \\
\text { genital itching }\end{array}$ & [13] \\
\hline Asteraceae & Tussilago farfara & $\begin{array}{l}\text { Aerial part, } \\
\text { capitulum, leaf }\end{array}$ & $\begin{array}{l}\text { Foot ache, } \\
\text { cough, expectorant }\end{array}$ & [13] \\
\hline
\end{tabular}


Continuation of Table 1.

\begin{tabular}{|c|c|c|c|c|}
\hline Berberidaceae & $\begin{array}{l}\text { Epimedium } \\
\text { pinnatum }\end{array}$ & Whole plant & Antioxidant and antimicrobial & [14] \\
\hline Berberidaceae & $\begin{array}{l}\text { Epimedium } \\
\text { pubigerum }\end{array}$ & Aerial parts & $\begin{array}{l}\text { Epimedium contains icariin, which } \\
\text { has demonstrated in vitro PDE5 } \\
\text { inhibitory properties }\end{array}$ & [15] \\
\hline Boraginaceae & $\begin{array}{l}\text { Omphalodes } \\
\text { cappadocica }\end{array}$ & Whole plant & Antimicrobial activity & [16] \\
\hline Boraginaceae & $\begin{array}{l}\text { Trachystemon } \\
\text { orientalis }\end{array}$ & $\begin{array}{l}\text { Leaves, } \\
\text { petiols, } \\
\text { stems }\end{array}$ & $\begin{array}{l}\text { Traditional medicine for human } \\
\text { treatments }\end{array}$ & $\begin{array}{l}{[17]} \\
{[18]}\end{array}$ \\
\hline Campanulaceae & $\begin{array}{l}\text { Campanula } \\
\text { latifolia }\end{array}$ & $\begin{array}{l}\text { Flowers, } \\
\text { leaves, root }\end{array}$ & $\begin{array}{l}\text { Contains up to } 400 \mathrm{mg} \% \text { of vitamin } \\
\text { C }\end{array}$ & [19] \\
\hline Campanulaceae & $\begin{array}{l}\text { Campanula } \\
\text { rapunculoides }\end{array}$ & $\begin{array}{l}\text { Leaves, } \\
\text { young } \\
\text { shoots }\end{array}$ & $\begin{array}{l}\text { The plant has been used as a cure for } \\
\text { hydrophobia in Russia. }\end{array}$ & [20] \\
\hline Caprifoliaceae & Sambucus ebulus & $\begin{array}{l}\text { Leaves, } \\
\text { fruit }\end{array}$ & $\begin{array}{l}\text { Wounds, hurts } \\
\text { Hemorrhoids Stomachache }\end{array}$ & [13] \\
\hline Chenopodiaceae & Atriplex nitens & Whole plant & $\begin{array}{l}\text { Anticancer and Antioxidant } \\
\text { activity }\end{array}$ & [21] \\
\hline Cistaceae & Cistus salviifolius & Whole plant & As sedative and expectorant & [22] \\
\hline Cruciferae & Bunias orientalis & Aerial parts & $\begin{array}{l}\text { Raw plant material for a higher } \\
\text { exposure to bioactive } \\
\text { phytochemicals such as } \\
\text { glucosinolates, their hydrolysis } \\
\text { products, and also phenolics, } \\
\text { flavonoids, and vitamins such as } \\
\text { vitamin C }\end{array}$ & [23] \\
\hline Cruciferae & $\begin{array}{l}\text { Cardamine } \\
\text { impatiens }\end{array}$ & Whole plant & Nervous diseases & [24] \\
\hline Cruciferae & $\begin{array}{l}\text { Raphanus } \\
\text { raphanistrum }\end{array}$ & Leaves & Treatment of obesity & [25] \\
\hline Cuscutaceae & $\begin{array}{l}\text { Cuscuta } \\
\text { campestris }\end{array}$ & Whole plant & Purgative, constipation & [26] \\
\hline Cypraceae & Cyperus longus & Aerial parts & Decreasing hair growth & [27] \\
\hline Dennstaedtiaceae & $\begin{array}{l}\text { Pteridium } \\
\text { aquilinum }\end{array}$ & $\begin{array}{l}\text { Rhizomes, } \\
\text { leaves }\end{array}$ & $\begin{array}{l}\text { Both bracken rhizomes were used in } \\
\text { folk medicine }\end{array}$ & [28] \\
\hline Dipsacaceae & Succisa pratensis & Root & $\begin{array}{l}\text { Use a decoction made from the } \\
\text { rootstock to treat coughs, sore } \\
\text { throat, bronchitis, fever and internal } \\
\text { inflammation. }\end{array}$ & [29] \\
\hline Droseraceae & $\begin{array}{l}\text { Drosera } \\
\text { rotundifolia }\end{array}$ & Whole plant & Various breathing problems & [30] \\
\hline Euphorbiaceae & $\begin{array}{l}\text { Euphorbia } \\
\text { paralias }\end{array}$ & Whole plant & $\begin{array}{l}\text { Has potent antifungal activity that is } \\
\text { capable of treating Dermatophytic } \\
\text { infection in vivo }\end{array}$ & [31] \\
\hline Euphorbiaceae & $\begin{array}{l}\text { Euphorbia } \\
\text { amygdaloides }\end{array}$ & Whole plant & $\begin{array}{l}\text { Use to fight infections, warts and } \\
\text { freckles. }\end{array}$ & [32] \\
\hline \multirow[t]{2}{*}{ Ericaceae } & Arbutus unedo & Root & Antimicrobial activity & [33] \\
\hline & Calluna vulgaris & Aerial parts & Skin cancer & [34] \\
\hline
\end{tabular}


Continuation of Table 1.

\begin{tabular}{|c|c|c|c|c|}
\hline Ericaceae & Erica arborea & $\begin{array}{l}\text { The } \\
\text { flowering } \\
\text { tips }\end{array}$ & $\begin{array}{l}\text { Renal lithiasis, } \\
\text { used in a decoction as a } \\
\text { diuretic and a urinary } \\
\text { antiseptic }\end{array}$ & [35] \\
\hline Ericaceae & $\begin{array}{l}\text { Rhododendron } \\
\text { sochadzeae }\end{array}$ & Leaves & Analgesic effect & [36] \\
\hline Ericaceae & $\begin{array}{l}\text { Rhododendron } \\
\text { luteum }\end{array}$ & $\begin{array}{l}\text { Whole } \\
\text { plant }\end{array}$ & $\begin{array}{l}\text { Toxic, but also has medicinal } \\
\text { uses. }\end{array}$ & $\begin{array}{r}37][38] \\
{[39]}\end{array}$ \\
\hline Ericaceae & $\begin{array}{l}\text { Vaccinium } \\
\text { arctostophyllos }\end{array}$ & Berries & Therapeutic effects & [40] [41] \\
\hline Fagaceae & Castanea sativa & $\begin{array}{l}\text { Seed, } \\
\text { leaves }\end{array}$ & Diet and therapy & [42] \\
\hline Fagaceae & $\begin{array}{l}\text { Quercus } \\
\text { hartwissiana }\end{array}$ & Leaves & $\begin{array}{l}\text { Traditional medicine for } \\
\text { human treatments }\end{array}$ & [43] \\
\hline Gentianaceae & $\begin{array}{l}\text { Centaurium } \\
\text { pulchellum }\end{array}$ & $\begin{array}{l}\text { The whole } \\
\text { flowering } \\
\text { and fruiting } \\
\text { herb }\end{array}$ & $\begin{array}{l}\text { A decoction is used for gastric } \\
\text { and abdominal pain, } \\
\text { hypertention, renal colic, } \\
\text { rheumatic pains and for the } \\
\text { elimination of stones from the } \\
\text { kidney and urethera. } \\
\text { An infusion of the herb is used } \\
\text { for diabetes. }\end{array}$ & $\begin{array}{r}{[44][45]} \\
{[46]}\end{array}$ \\
\hline Geraniaceae & $\begin{array}{l}\text { Erodium } \\
\text { cicutarium }\end{array}$ & Herb & For hemorrhoids & [47] \\
\hline Gramineae & $\begin{array}{l}\text { Echinochloa crus- } \\
\text { galli }\end{array}$ & $\begin{array}{l}\text { Mature } \\
\text { plants }\end{array}$ & Herbicide sprey & [48] \\
\hline Gramineae & $\begin{array}{l}\text { Paspalum } \\
\text { paspalodes }\end{array}$ & Toxic plant & Tremorgenic mycotoxicosis & [49] \\
\hline Gramineae & Setaria glauca & $\begin{array}{l}\text { Nuisance } \\
\text { weed }\end{array}$ & $\begin{array}{l}\text { Cause stomatitis in cattle } \\
\text { and horses }\end{array}$ & {$[50]$} \\
\hline Grossulariaceae & Ribes biebersteinii & Fruit & Against anemia & [47] \\
\hline Guttiferae & $\begin{array}{l}\text { Hypericum } \\
\text { tetrapterum }\end{array}$ & $\begin{array}{l}\text { Whole } \\
\text { plant }\end{array}$ & $\begin{array}{l}\text { Antimicrobial and antioxidant } \\
\text { activities of the essential oil }\end{array}$ & [51] \\
\hline Iridaceae & Iris lazica & $\begin{array}{l}\text { The juice } \\
\text { of the fresh } \\
\text { roots }\end{array}$ & $\begin{array}{l}\text { Cosmetic and for the removal } \\
\text { of freckles from the skin. }\end{array}$ & [52] \\
\hline Lamiaceae & Ajuga reptans & $\begin{array}{l}\text { Mature } \\
\text { leaves or } \\
\text { storage } \\
\text { organs }\end{array}$ & $\begin{array}{l}\text { Carbohlydrate components for } \\
\text { traditional medicine }\end{array}$ & [53] \\
\hline Lamiaceae & $\begin{array}{l}\text { Lamium } \\
\text { maculatum var. } \\
\text { maculatum }\end{array}$ & Aerial parts & $\begin{array}{l}\text { Used in the Chinese Folk } \\
\text { Medicine for treatment of } \\
\text { Trauma, fracture and } \\
\text { hypertension }\end{array}$ & {$[54][55]$} \\
\hline Lamiaceae & $\begin{array}{l}\text { Lycopus } \\
\text { europaeus }\end{array}$ & whole herb & $\begin{array}{l}\text { An ayurvedic medicine which } \\
\text { is used as anti-inflammatory } \\
\text { agent. }\end{array}$ & {$[56]$} \\
\hline Lamiaceae & $\begin{array}{l}\text { Origanum vulgare } \\
\text { subsp. vulgare }\end{array}$ & Aerial parts & $\begin{array}{l}\text { The aqueous extract for } \\
\text { embryo development. }\end{array}$ & [57] \\
\hline
\end{tabular}


Continuation of Table 1.

\begin{tabular}{|c|c|c|c|c|}
\hline Lamiaceae & Prunella vulgaris & fruit- & $\begin{array}{l}\text { Traditional Chinese } \\
\text { medicine }\end{array}$ & $\begin{array}{r}{[58][59]} \\
{[60]}\end{array}$ \\
\hline & & & $\begin{array}{l}\text { its water extract for } \\
\text { therapeutic use is } \\
\text { prepared from the dried } \\
\text { fruit-spikes of medicine } \\
\text { that has been used for } \\
\text { the treatment of } \\
\text { headache, dizziness due } \\
\text { to hypertension, } \\
\text { tinnitus, conjunctivitis, } \\
\text { dry cough, dermatitis } \\
\text { and boils, high blood } \\
\text { pressure and skin } \\
\text { allergic diseases. }\end{array}$ & \\
\hline Leguminosae & Genista tinctoria & Aerial parts & $\begin{array}{l}\text { Use to treat tobacco } \\
\text { addiction }\end{array}$ & [61] \\
\hline Leguminosae & Vicia peregrina & Seed & Diets & [62] \\
\hline Leguminosae & Medicago lupulina & Aerial parts & $\begin{array}{l}\text { Antibacterial properties } \\
\text { against micro-organisms }\end{array}$ & [63] \\
\hline Leguminosae & Melilotus alba & Aerial parts & $\begin{array}{l}\text { Extracts for antibacterial } \\
\text { and antitumor activities }\end{array}$ & [64] \\
\hline Leguminosae & $\begin{array}{l}\text { Robinia } \\
\text { pseudoacacia }\end{array}$ & Flowers & Antioxidant & [65] \\
\hline Liliaceae & $\begin{array}{l}\text { Ornithogalum } \\
\text { sigmoideum }\end{array}$ & Leaves & $\begin{array}{l}\text { Play a major role in } \\
\text { initiating thrombus } \\
\text { formation which occurrs } \\
\text { with various thrombotic } \\
\text { disorders, including } \\
\text { hypertension, } \\
\text { atherosclerosis and } \\
\text { ischemic heart diseases. }\end{array}$ & [66] \\
\hline Loranthaceae & $\begin{array}{l}\text { Viscum album subsp. } \\
\text { austriacum }\end{array}$ & Whole plant & $\begin{array}{l}\text { Herbal preparations are } \\
\text { traditionally used in two } \\
\text { main therapeutic areas } \\
\text { for cardiovascular } \\
\text { disorders and in } \\
\text { oncology }\end{array}$ & [67] \\
\hline Lythraceae & Lythrum salicaria & $\begin{array}{l}\text { The dried } \\
\text { herbal parts }\end{array}$ & $\begin{array}{l}\text { Has a wide range of } \\
\text { beneficial health effects. } \\
\text { Its pharmacological } \\
\text { activity is mostly due to } \\
\text { its phenolic compounds, } \\
\text { mainly tannins. }\end{array}$ & [68] \\
\hline Oleaceae & Osmanthus decorus & Leaves & Herbal drug & [69] \\
\hline Osmundaceae & Osmunda regalis & Rhizome & $\begin{array}{l}\text { For the treatment of } \\
\text { bone fractures, joint } \\
\text { disorders and rheumatic } \\
\text { and arthritic pain }\end{array}$ & [70] \\
\hline
\end{tabular}


Continuation of Table 1.

\begin{tabular}{|c|c|c|c|c|}
\hline Primulaceae & $\begin{array}{l}\text { Anagalis arvensis var. } \\
\text { caerulea }\end{array}$ & Whole plant & $\begin{array}{l}\text { Used for depression, } \\
\text { tuberculosis, liver complaints, } \\
\text { epilepsy, dropsy, and } \\
\text { rheumatism. Externally extract } \\
\text { of this species used for } \\
\text { improving the complexion, } \\
\text { especially for freckles. }\end{array}$ & [71] \\
\hline Primulaceae & Pirimula megaseifolia & Whole plant & $\begin{array}{l}\text { Traditional medicine for human } \\
\text { treatments }\end{array}$ & [72] \\
\hline Primulaceae & Primula vulgaris & $\begin{array}{l}\text { Leaves, } \\
\text { roots }\end{array}$ & $\begin{array}{l}\text { Human Pathogenic } \text { Bacterial } \\
\text { Strains }\end{array}$ & [73] \\
\hline Polygonaceae & Rumex acetosella & Leaves & $\begin{array}{l}\text { Diabetes, stomach and heart } \\
\text { diseaes }\end{array}$ & {$[74]$} \\
\hline Polypodiaceae & $\begin{array}{l}\text { Polypodium vulgare } \\
\text { subsp. vulgare }\end{array}$ & Rhizomes & $\begin{array}{l}\text { Herbal preparations in solid } \\
\text { dosage forms for oral use }\end{array}$ & [75] \\
\hline Polypodiaceae & Blechnum spicant & $\begin{array}{l}\text { Leaflets, } \\
\text { fronds, } \\
\text { root }\end{array}$ & $\begin{array}{l}\text { The leaflets have been chewed } \\
\text { in the treatment of internal } \\
\text { cancer, lung disorders and } \\
\text { stomach problems. The fronds } \\
\text { are used externally as a } \\
\text { medicine for skin sores. A } \\
\text { decoction of the root has been } \\
\text { used in the treatment of } \\
\text { diarrhoea. }\end{array}$ & [76] \\
\hline Ranunculaceae & $\begin{array}{l}\text { Ranunculus ficaria } \\
\text { subsp. bulbifera }\end{array}$ & Leaves & $\begin{array}{l}\text { Used for wound healing and } \\
\text { hemorrhoids }\end{array}$ & $\begin{array}{l}{[77]} \\
{[78]} \\
{[79]} \\
{[80]}\end{array}$ \\
\hline Rhamnaceae & Frangula alnus & $\begin{array}{l}\text { Bark, } \\
\text { branches }\end{array}$ & $\begin{array}{l}\text { Treatment of headaches } \\
\text { Dried, whole or fragmented bark } \\
\text { of the stems and } \\
\text { branches, standardised; } \\
\text { standardised herbal } \\
\text { preparations thereof }\end{array}$ & $\begin{array}{l}{[81]} \\
{[82]}\end{array}$ \\
\hline Rosaceae & Aruncus vulgaris & $\begin{array}{l}\text { Fresh aerial } \\
\text { parts }\end{array}$ & $\begin{array}{l}\text { Traditional medicine for human } \\
\text { treatments }\end{array}$ & [83] \\
\hline Rosaceae & Fragaria vesca & Strawberry & Antioxidant & [84] \\
\hline Rosaceae & $\begin{array}{l}\text { Laurocerasus } \\
\text { officinalis }\end{array}$ & Fruit & Antioxidant & [85] \\
\hline Rosaceae & Potentilla reptans & Aerial parts & $\begin{array}{l}\text { Traditional medicine for human } \\
\text { treatments }\end{array}$ & [86] \\
\hline Rosaceae & Rosa canina & Aerial parts & $\begin{array}{l}\text { İs used for the prevention and } \\
\text { treatment of the common cold, } \\
\text { gastrointestinal disorders, } \\
\text { diabetes, kidney disorders, and } \\
\text { other infections }\end{array}$ & [87] \\
\hline Rosaceae & Rubus idaeus & Fruit & $\begin{array}{l}\text { Use of raspberry as a cure for } \\
\text { renal diseases in Chinese } \\
\text { traditional medical practice. }\end{array}$ & [88] \\
\hline
\end{tabular}


Continuation of Table 1.

\begin{tabular}{|c|c|c|c|c|}
\hline Rosaceae & Rubus platyphyllos & Fruit & Antioxidant & [88] \\
\hline Rosaceae & Rubus caucasicus & Fruit & Antioxidant & [88] \\
\hline Scrophulariaceae & Veronica persica & Aerial parts & Pharmacological activity & [89] \\
\hline Smilacaceae & Smilax excelsa & Fruit & $\begin{array}{l}\text { Used in Chinese traditional } \\
\text { system of medicines as } \\
\text { anticancer, anti-inflammatory } \\
\text { and analgesic agents }\end{array}$ & [90] \\
\hline Solanaceae & Solanum dulcamara & $\begin{array}{l}\text { Bark of the } \\
\text { root, twigs }\end{array}$ & $\begin{array}{l}\text { Use it as a poultice for gout, } \\
\text { herpes, furuncles, warts, } \\
\text { ringworms, shingles, old ulcers, } \\
\text { and felons }\end{array}$ & [91] \\
\hline Thymelaeaceae & Daphne pontica & $\begin{array}{l}\text { Aerial Parts, } \\
\text { roots }\end{array}$ & $\begin{array}{l}\text { Traditional medicine for human } \\
\text { Treatments }\end{array}$ & [92] \\
\hline Umbelliferae & Angelica sylvestris & Leaves & Antioxidant & [93] \\
\hline Umbelliferae & Hydrocotyle ramiflora & Aerial Parts & Antioxidant & [94] \\
\hline Urticaceae & Urtica dioica & $\begin{array}{l}\text { Leaves, } \\
\text { herb, } \\
\text { seed }\end{array}$ & $\begin{array}{l}\text { Against goiter, hemorrhoids, } \\
\text { urinary system infections, } \\
\text { stomach disorders, dyspnea, } \\
\text { bronchitis, hypertension, } \\
\text { infertility (for women); as } \\
\text { analgesic } \\
\text { Against cancer, stomachache, } \\
\text { gastric ulcer, goiter. }\end{array}$ & [47] \\
\hline Violaceae & Viola suavis & Aerial Parts & $\begin{array}{l}\text { Treatments for colds and } \\
\text { bronchitis }\end{array}$ & [95] \\
\hline
\end{tabular}

Aromatic and medicinal plants have a significant role in human health. These roles have been resulted mainly from their different chemical contents. Different parts of them such as leaf, bark, root, seed, fruit and flower has been used for these purposes. Traditional usages of these plants are important in projection of discovery new drugs.

As a result of the developments in agricultural techniques using of wild plants was remarkably decreased [96]. Many of vascular plant taxa have nutritionally importance and they can be used as medicine. They have been used alternatively for the poverty problems as well [97]. Therefore, determining chemical contents of wild vascular plant taxa is important in order to use them as medicine. So, ethno medicinal uses of the identified plant taxa have been reported in the present study. In the present study, $81(77 \%)$ out of 105 vascular plant taxa were found to have medicinal and aromatic potential. The parts of these plant taxa, which have been identified, used for different purposes are explained in detail.

\section{CONCLUSION}

A great variety of vascular plants was used by traditional healers for treatment of some diseases. Protective measures are necessary for the conservation of the natural herbal resources, because of avoiding their overexploitation. Unfortunately, local people are fast losing some of their most important traditional using of valuable wild plant species. It is important that we collect and record information as soon as possible. The present study also showed that medicinal plants continue to play an important role in the primary healthcare system. Fresh part of the plant is used for the preparation of the medicine but if fresh plant parts are not suitable in that moment dried parts of plant can be used.

Pinus sylvestris has special ecological conditions in Sürmene-Çamburnu (Trabzon) region, because of its unexpected distribution here. In the NE Anatolia the distribution of Pinus 
sylvestris is descending down to the beach. This forest is a sensitive ecosystem which has fragile structure. Because of its floristic contents and vegetation structure this Scots pine forest is a unique ecosystem that it is assignment as Nature Park. For this reason, we need to consider the conservation and utilization equilibrium while using the plant species in this kind of areas. With this study, we believe that we will contribute to future ethnobatanical and ethnomedicinal studies.

\section{Acknowledgement}

This study is a part of $\mathrm{PhD}$ thesis of corresponding author.

\section{Conflict of Interests}

Authors declare that there is no conflict of interests.

\section{REFERENCES}

[1] Koçyiğit, M. (2005). Yalova İlinde Etnobotanik Bir Araştırma, Yüksek Lisans Tezi, İstanbul Üniversitesi Sağlık Bilimleri Enstitüsü.

[2] Baytop, T. (1994). Türkçe Bitki Adları Sözlüğü. Atatürk Kültür, Dil ve Tarih Yüksek Kurumu, Türk Dil Kurumu Yayınları, ISBN: 975-16-0542-3, No:578, 508 s., Ankara.

[3] Özkan, Z.C. \& Akbulut, S. (2012). Trabzon İlinin Etnobotanik Özellikleri. KTU BAP, Proje No:1098, Trabzon.

[4] European Medicines Agency, Science Medicines Health (2011). EMA/HMPC/289432/2009 Committee on Herbal Medicinal Products (HMPC), Assessment report on Hedera helix L., folium.

[5] Gruenwald, J., Brendler, T., Jaenicke, C. (2000). PDR for Herbal Medicines. Medical Economics Company, Montvale, 284-5. 3.

[6] Blumenthal, M. Herbal Medicine Expanded Commission E. Monographs (2000). 1st ed. Austin, 215-218.

[7] Lutsenko, Y., Bylka, W., Matławska, I., \& Darmohray, R. (2010). Hedera helix as a medicinal plant, kerva polonica, Vol 56, No 1.

[8] Sezik, E., Yesilada, E., Honda, G., Takaishi, Y., Takeda, Y., Tanaka, T. (2001). Traditional medicine in Turkey X. Folk medicine in Central Anatolia. J. Ethnopharmacol. 75:95-115.

[9] Kilic, O. (2013). Essential oil compounds of three Centaurea L. taxa from Turkey and their chemotaxonomy, Journal of Medicinal Plants Research, Vol. 7(19), pp. 1344-1350, DOI: 10.5897/JMPR12.1233, ISSN 1996-0875.

[10] Ribeiro-Varandas, E., Ressurreiçao, F., Viegas, W. \& Delgado, M. (2014). Cytotoxicity of Eupatorium cannabinum L. ethanolic extract against colon cancer cells and interactions with Bisphenol A and Doxorubicin. BMC Complement Altern Med. doi: 10.1186/14726882-14-264.

[11] URL 1. 13.02.2017, www.luontoportti.com > Plants > Flowers.

[12] Altundaga, E. \& Ozturk, M. (2011). Ethnomedicinal studies on the plant resources of east Anatolia, Turkey, The 2nd International Geography Symposium GEOMED2010, ELSEVIER, ScienceDirect, Procedia Social and Behavioral Sciences 19, 756-777.

[13] Kızılarslan, Ç. \& Özhatay, N. (2012). Wild Plants Used as Medıcınal Purpose in the South Part Of İzmit (Northwest Turkey), Original article, Turk J. Pharm. Sci., 9(2), 199-218.

[14] Mahboub1, M., Kazempour, N., Hosseın1, H. \& Mahboub1, M. (2013). Antimicrobial and antioxidant activity of Epimedium pinnatum, Experımental Paper, kerva polonica, Vol. 59 No. 2 DOI: 10.2478/hepo-2013-0009. 
[15] URL 2. 03.12.2016, https://en.wikipedia.org/wiki/Epimedium.

[16] İskender, Y., Kahriman, N., Yücel, M., Alpay, Karaoğlu, Ş., Terzioğlu, S., Yayli, N. (2011). Antimicrobial activity and Volatile Constituents of Omphalodes cappadocica (Willd.) DC., Asian Journal of Chemistry, Vol.23, Pp.1032-1034.

[17] Akçin, Ö.E., Kandemir, N. \& Akçin, Y. (2004). A Morphological and Anatomical Study on a Medicinal and Edible Plant Trachystemon orientalis (L.) G.Don ( Boraginaceae ) in the Black Sea Region, Turk J Bot, 28, 435-442.

[18] Doğru-Koca, A. \& Yıldırımlı, Ş. (2010). Ethnobotanical Properties of Akçakoca District in Düzce (Turkey), Hacettepe Journal of Biology and Chemistry, Hacettepe J. Biol. \& Chem., 38 (1), 63-69.

[19]URL 3. 11.07.2016. http://www.pfaf.org/user/plant.aspx?latinname=Campanula+latifolia.

[20] URL 4. 03.05.2016. http://www.naturalmedicinalherbs.net/herbs.

[21] Aboul-Enein, A.M., Abu El-Ela, F., Shalaby, E.A. \& El-Shemy, H.A. (2012). Traditional medicinal plants research in Egypt: Studies of antioxidant and anticancer activities, Full Length Research Paper, Journal of Medicinal Plants Research Vol. 6(5), pp. 689-703, DOI: 10.5897/JMPR11.968 ISSN 1996-0875.

[22] Koçyiğit, M. \& Özhatay, N. (2006). Wild Plants Used as Medicinal Purpose in Yalova (Northwest Turkey), Turkish J. Pharm. Sci., 3 (2), 91-103.

[23] URL 5. 01.12.2016. http://pubs.acs.org/doi/abs/10.1021/jf052756t.

[24] Pande, PC., Tiwari, L. \& Pande, HC. (2007). Ethnoveterinary plants of Uttaranchal - A Review, Indian Journal of Tradational Knowladge, Vol. 6 (3), pp. 444-458.

[25] Conforti, F., Perri, V., Menichini, F., Marrelli, M., Uzunov, D., Statti, G.A. \& Menichini, F. (2011). Wild Mediterranean Dietary Plants as Inhibitors of Pancreatic Lipase, Phytotherapy Research Phytother. Published online in Wiley Online Library (wileyonlinelibrary.com) DOI: 10.1002/ptr.3603.

[26] Youssef, R.S.A. (2013). Medicinal and non-medicinal uses of some plants found in the middle region of Saudi Arabia, Full Length Research Paper, Journal of Medicinal Plants Research, Vol. 7(34), pp. 2501-2513, DOI: 10.5897/JMPR12.798, ISSN 1996-0875.

[27] AbouZid, S.F. \& Mohamed, A.A. (2011). Survey on medicinal plants and spices used in Beni-Sueif, Upper Egypt, Journal of Ethnobiology and Ethnomedicine, Page 2 of 6.

[28] Madeja, J., Harmata, K., Kołaczek, P., Karpıńska-Kołaczek, M., Pıątek, K. \& Naks, P. (2009). Bracken (Pteridium aquilinum(L.) Kuhn), mistletoe (Viscum album (L.)) and bladder-nut (Staphylea pinnata (L.)) - mysterious plants with unusual applications. Cultural and ethnobotanical studies, Plants and Culture: seeds of the cultural heritage of Europe, Edipuglia s.r.l. - www.edipuglia.it.

[29] URL6.21.11.2016.https://www.herbal-supplement-resource.com/devils-bit-scabious.html.

[30] URL 7. 11.11.2016. http://www.webmd.com/vitamins-supplements.

[31] Berfad, M.A., Alnour, T.M.S. \& Shakurfow, F. A. (2013). Treatment of Two Cases of Tinea capitis by Euphorbia paralias Matrix (Case Study), Journal of Medicinal Plants Studies, Volume: 1, Issue: 3 First page: (87) Last page: (90) ISSN: 2320-3862.

[32] URL 8. 02.02.2017. http:// titan-medicalplant.blogspot.com.tr/2011/11/wood-spurge. html.

[33] Dib, M.A., Djabou, N., Allal1, H. \& Tabt1, B. (2010). Identification of Phenolic Compounds and Antimicrobial Activity of Roots of Arbutus unedo L., Asian Journal of Chemistry, Vol. 22, No. 5, 4045-4053. 
[34] IUCN (2005). A Guide to Medicinal Plants in North Afrika, Cover Design by: Chadi Abi Faraj, Produced by: IUCN Centre for Mediterranean Cooperation, ISBN: 2-8317-0893-1, A Guide to Medicinal Plants in North Africa (Malaga, Spain).

[36] Mohajje-Nayebi, A., Nazemiyeh, H., Omidbakhsh, R. \& Çobanoglu, S. (2008). Analgesic effect of the methanol extract of Erica arborea (L.) in mice using formalin test, DARU Vol. 16, No. 4.

[37] Alan, S., Kürkcücoglu, M., Göger, F., Can-Bașer, H.K. (2010). Morphological, chemical and indumentum characteristics of Rhododendron luteum Sweet (Ericaceae). Pak. J. Bot., 42(6), 3729-3737.

[38] Parfionov, W.I. (1987). Po Stronicam Krasnoy Knigi. Bielorusskaya Sovietskaya Enciklopedia, Minsk.

[39] Marin, C., Cantor, M., Szatmarı, P. \& Sicora, C. (2014). Rhododendron luteum Sweet. and Rhododendron hirsutum L. in Habitats from Central Europe, Bioflux, ProEnvironment, 7, $165-172$.

[40] Amin, G. (1991). Popular Medicinal Plants of Iran, Vol. 1. Tehran, Research Deputy of Health Ministry, p. 126.

[41] Nickavar, B. \& Amin G. (2004). Anthocyanins from Vaccinium arctostaphylos Berries, Pharmaceutical Biology, Vol. 42, Nos. 4-5, pp. 289-291.

[42] Živković, J., Mujić, I., Zeković, Z., Nikolić, G., Vidović, S. \& Mujić, A. (2009). Extractıon And Analysıs Of Condensed Tannıns In Castanea Satıva Mill., Ekstrakcija I Analiza Kondenzıranıh Tanına Castanea Satıva Mı1., Orıgınal Paper, Journal Central European Agriculture, 10(3), 283-288.

[43] Kaya, M., Cenesız, M., Onder, F., Ucar, Ö., Uzun, M. \& Yıldız, S. (2006). GnRH-Induced LH Secretion in Prepubertal female fat-tailed Lambs fed with tannin-rich Oak Leaves (Quercus hartwissiana), Revue Méd. Vét., 157, 7, 387-390.

[44] Britton, N.L. \& Brown, H.A. (1970). An illustrated Flora of the Northern United States and Canada. Vol. III. Dover Publ. Inc., New York.

[45] Rizk, A.M. \& El-Ghazaly, G.A. (1995). Medicinal and Poisonous Plants of Qatar University of Qatar, Doha.

[46] URL 9. 11.11.2015. http://www.uicnmed.org/nabp/web/documents/book/chapter3.pdf.

[47] Özgen, U., Kaya, Y. \& Houghton, P. (2010). Folk medicines in the villages of Ilıca District (Erzurum, Turkey), Turk J Biol, 36, 93-106, doi:10.3906/biy-1009-124.

[48] Maun, M.A. \& Barret, S.C.H. (1986). The biology of Canadian weeds. Echinochloa crusgalli L. Beauv. Can. J. Plant Sci., 66, 739-759.

[49] Moyano, M.R., Molina, A.M., Lora, A.J., Mendez, J. \& Rueda, A. (2010). Tremorgenic mycotoxicosis caused by Paspalum paspaloides (Michx.) Scribner infected by Claviceps paspali: a case report, Case Report, Veterinarni Medicina, 55, 336-338.

[50] Steel-Marion, G., Cavers-Paul, B. \& Lee-Susanne M. (1983). The Biology of Canadian Weeds. 59. Setaria glauca (L.) Beauv. and S. verticillats (L.) Beauv., Can. J. Plant Sci, 63, $711-725$.

[51] Đorđević, A., Šmelcerović, A., Veličković, D., Stankov-Jovanović, V., Mitić, V., Kostić, D. \& Palić, R. (2010). Antimicrobial and antioxidant activities of essential oil and crude extracts of Hypericum tetrapterum Fries (Hypericaceae), Vol.4(14), 1441-1445, DOI: 10.5897/JMPR10.116, ISSN: 1996-0875.

[52] URL 10. 21.03.2016, http://www.botanical.com/botanical/mgmh/i/irises08.html\#med. 
[53] Bachmann, M., Matile, P., \& Keller, F. (1994). Metabolism of the Raffinose Family Oligosaccharides in Leaves of Ajuga reptans. Cold Acclimation, Translocation, and Sink to Source Transition: Discovery of Chain Elongation Enzyme. Plant Physiol, 105, 13351345. C.,

[54] Shuya, C., Xingguo, C., \& Zhide, H. (2003). Biomed. Chromatogr. Biochem. Syst. Ecol., $28,891$.

[55] Alipieva, K.I., Taskova, R.M., Jensen, S.R., \& Handjieva, N.V. (2006). Iridoid glucosides from Lahium album and Lamium maculatum (Lamiaceae), ELSEVIER, Biochemical Systematics and Ecology, 34, 88-91.

[56] Aziz, A., Hussain, M., Raza, S.M., Khan, I.A., Munawar, S.H., Manzoor, Z., \& Saleem, M. (2014). In vitro anti-inflammatory activity of Lycopus europaeus Linn., International Journal of Pharma Sciences, Vol. 4, No. 4, 689-691.

[57] Benavides, V., D’Arrigo, G. \& Pino J. (2010). Effects of aqueous extract of Origanum vulgare L. (Lamiaceae) on the preimplantational mouse embryos, Efecto del extracto acuoso de Origanum vulgare L. (Lamiaceae) en embriones preimplantacionales de ratón, Rev. peru. biol. 17(3): 381 - 384, Facultad de Ciencias Biológicas UNMSM, ISSN: $1727-$ 9933.

[58] World Health Organization (1989). WHO Regional Publications, Western Pacific Series No.2, Medicinal Plants in China - A selection of 150 commonly used species., P. 231.

[59] Shin, T.Y., Kim, Y.K, Kim, H.M. (2001). Inhibition of Immediate-type allergic reactions by Prunella vulgaris in a murine model, Immunopharmacol Immunotoxicol, 23(3), 423-35.

[60] Cheng, C-L. \& Xu, H. (2006). Antiviral and Immunomodulatory Properties of Prunella vulgaris, Asian Journal of Traditional Medicines, 1-5.

[61] Tero-Vescan, A., Varı, C.E. \& Vlase, L. (2014). Alkaloıd Content Of Some Potential Isoflavonoids Sources (NATIVE Genista Species) Long-Term Safety Implications, Farmacia, Vol. 62, 6.

[62] Buyukcapar, H.M. \& Kamalak, A. (2006). Raw and heat-treated culban (Vicia peregrina) seed as protein source for mirror carp (Cyprinus carpio) fingerlings, South African Journal of Animal Science, 36 (4).

[63] URL 11. 21.11.2016. www.naturalmedicinalherbs.net/herbs/m/medicago-lupulina.

[64] Pehlivan-Karakaş F., Yıldırım, A., \& Türker, A. (2012). Biological screening of various medicinal plant extracts for antibacterial and antitumor activities, Turk J Biol, 36, 641-652, TÜBİTAK doi:10.3906/biy-1203-16.

[65] Ji1, H-f., Du, A-1., Zhang, L-w., Xu, C-y., Yang, M-d., \& Li, F-f. (2012). Effects of drying methods on antioxidant properties in Robinia pseudoacacia L. flowers, Full Length Research Paper, Journal of Medicinal Plants Research, Vol. 6(16), pp. 3233-3239, DOI: 10.5897/JMPR12.107 ISSN 1996-0875.

[66] Yarat, A., Yanardag, R. \& Özgür, S. (2010). Effect of Some Medicinal Plants Grown in Turkey on Platelet Aggregation, The 2nd International Symposium on Medicinal Plants, Their Cultivation and Aspects of Uses, Abstracts Book, Petra- Jordan.

[67] European Medicines Agency, Science Medicines Health (2012). Assessment report on Viscum album L., herba, EMA/HMPC/246778/2009 Committee on Herbal Medicinal Products (HMPC).

[68] Suhad, S., Humadi, S.S. \& Viorica-Istudor V. (2009). Lythrum Salicaria (Purple Loosestrife). Medicinal Use, Extraction and Identification of Its Total Phenolic Compounds, Farmacia, Vol.57, 2. 
[69] Do, T.K.T., Loffredo, L., Hadji-Minaglou, F., Antoniotti, S. \& Fernandez X., (2011). Initial Investigations on Four Species of Osmanthus by Hptlc, www.botanicert.com.

[70] Molına, M. (2009). Local Knowledge and Management of the Royal Fern (Osmunda regalis L.) in Northern Spain: Implications for Biodiversity Conservation, American Fern Journal 99(1):0-0.

[71] Gulshan, A.B., Dasti, A.A., Hussain, S., Atta, M.İ. \& Amin-ud-Din, M. (2012). Indigenous Uses of Medicinal Plants in Rural Areas of Dera Ghazi Khan, Punjab, Pakistan, ARPN Journal of Agricultural and Biological Science, vol. 7, no. 9.

[72] Schmidt-Lebuhn, A.N., M. de Vos, J., Keller, B. \& Conti, E. (2012). Phylogenetic analysis of Primula section Primula reveals rampant non-monophyly among morphologically distinct species, ELSEVIER, Molecular Phylogenetics and Evolution.

[73] Majid, A., Hassan, S., Hussain, W., Khan, A., Hassan, A., Khan, A., Khan, T., Ahmad, T. \& Ur- Rehman, M. (2014). In vitro Approaches of Primula vulgaris Leaves and Roots Extraction against Human Pathogenic Bacterial Strains, World Applied Sciences Journal 30 (5): 575-580.

[74] Kilic, O. \& Bagci, E. (2013). An ethnobotanical survey of some medicinal plants in Keban (Elazığ-Turkey), Full Length Research Paper, Journal of Medicinal Plants Research, Vol. 7(23), pp. 1675-1684.

[75] European Medicines Agency Evaluation of Medicines for Human Use (2008). Assessment Report on Polypodium vulgare L., Rhizoma, Doc. Ref.: EMEA/HMPC/600669.

[76] URL 12. 10.08.2016. http://www.naturalmedicinalherbs.net/herbs/b/blechnum-spicant.

[77] Uğurlu, E., Seçmen, Ö. (2008). Medicinal plants popularly used in the villages of Yunt mountain (Manisa-Turkey), Fitoterapia, 79, 126-131.

[78] Gürhan, G., Ezer, N. (2004). Plants used for hemorrhoid treatment in folk medicine I., Hacettepe University Journal of the Faculty of Pharmacy, 24, 37-55.

[79] Passalacqua, N.G., Guarrea, P.M., De-Fine, G. (2007). Constribution to the knowledge of the folk plant medicine in Calabria Region (Southern Italy), Fitoterapia, 78, 52-68.

[80] Erdoğan, T.F. (2013). Ranunculus Türlerinin Kimyasal Bileşikleri ve Biyolojik Aktiviteleri, Hacettepe Üniversitesi Eczacılık Fakültesi Dergisi, Cilt 33, Say1 1, ss. 105116.

[81] Cenıć-Milošević, D., Tambur, Z., Ivančajić, S., Bokonjıć, D., Čuković, A., Stanojković, T., Grozdanıć, N., Kulıšıć, Z. \& Juranıć, Z. (2013). Antiproliferative Effects of Camellia sinensis, Frangula alnus and Rosmartnus officinalis, Arch. Biol. Sci., Belgrade, 65(3), 885891.

[82] European Medicines Agency, Evaluation of Medicines for Human Use (2007). Assessment Report on Rhamnus frangula L., Cortex, Committee on Herbal Medicinal Products (HMPC), Doc. Ref: Emea/Hmpc/76306/2006.

[83] Baricevic, D., Bernáth, J., Maggioni, L. \& Lipman, E. (2002). Report of a Working Group on Medicinal and Aromatic Plants, Working Group on Medicinal and Aromatic Plants: First Meeting, IPGRI is a Future Harvest Centre supported by the Consultative Group on, International Agricultural Research (CGIAR).

[84] Buřičová, L., Andjelkovic, M., Čermáková, A., Réblová, Z., Jurček, O., Kolehmainen, E., Verhé R., Kvasnička, F. (2011). Antioxidant capacity and antioxidants of strawberry, blackberry, and raspberry leaves, Czech J. Food Sci., 29: 181-189.

[85] Kolayli, S,, Küçük, M., Duran, C., Candan, F. \& Dinçer B. (2003). Chemical and Antioxidant Properties of Laurocerasus officinalis Roem. (Cherry Laurel) Fruit Grown in 
the Black Sea Region, Agric. Food Chem., 51 (25), pp 7489-7494, DOI: 10.1021/jf0344486.

[86] Avc1, G., Kupeli, E., Eryavuz, A., Yesilada, E. \& Kucukkurt, I. (2006). Antihypercholesterolaemic and antioxidant activity assessment of some plants used as remedy in Turkish folk medicine, ELSEVIER, ScienceDirect, Journal of Ethnopharmacology, 107, 418-423.

[87] İlbay, Z., Şahin, S. \& Kırbaşlar, Ş.İ. (2013). Investigation of Polyhenolic Content of Rose Hip (Rosa canina L.) Tea Extracts: A Comparative Study, Foods 2, 43-52; doi:10.3390/foods2010043, ISSN 2304-8158.

[88] Zhang, Y., Zhang, Z., Yang, Y., Zu, X., Guan, D. \& Wang, Y. (2011). Diuretic Activity of Rubus idaeus L (Rosaceae) in Rats, Research Article, Tropical Journal of Pharmaceutical Research, 10(3), 243-248.

[89] Crışan, G., Vlase, L., Balıca, G., Muntean, D., Ştefănescu, C, Păltınean, R., Tămaş, M., Leucuţa, S. (2010). Lc /MS Analysis of Aucubin and Catalpol of Some Veronica Species, Farmacia, Vol.58, 2.

[90] Devi1, V.A., Arumugasamy, K.A., Shalimo,1 A., Nantha-Kumar R., Udhayasankar, M.R. \& Kokilavani, R. (2014). Anti-Inflammatory Activity of Smilax wightii fruit, Endemic A.DC. (Smilacaceaea) -An Endangered Medicinal Plant from the Nilgiris, Journal of Pharmaceutical and Biological Research, Research Article, ISSN:2347-8330, JPBR, Vol.2(2): 136-138.

[91] URL 13. 11.11.2016. http://medicinalherbinfo.org/herbs/CommonNightshade.html.

[92] Kumar, S., Bajwa, B.S., Kuldeep, S. \& Kalia, A.N. (2013). Anti-Inflammatory Activity of Herbal Plants: A Review, Internatıonal Journal of Advances in Pharmacy, Biology and Chemistry, IJAPBC - Vol. 2(2), ISSN: 2277-4688.

[93] Sharma, S.K., Singh, L., Singh, S., (2013). A Review on Medicinal Plants Having Antioxidant Potential, Indian Journal of Research in Pharmacy and Biotechnology, ISSN: 2321-5674 (Print), ISSN: 2320 - 3471.

[94] Huang, S-S., Huang, G-J., Ho, Y-L., Lin, Y-H., Hung, H-J., Tien-Ning, Chang, T-N., Chang M-J., Chen, J-J, \& Chang, Y-S. (2008). Antioxidant and antiproliferative activities of the four Hydrocotyle species from Taiwan, Botanical Studies Biochemistry 49: 311322 .

[95] URL 14. 11.02.2016. http://www.everygreenherb.com/viola.html.

[96] Yildırım, E, Dursun, A, Turan, M. (2000). Determination of the Nutrition Contents of the Wild Plants Used as Vegetables in Upper Çoruh Valley, Turkish Journal of Botany, 25, 369.

[97] Tukan, S., Takruri, H.R., Al- Eisawi D.M. (1998). The use of wild edible plants in the Jordiandiet, International Journal of Food Sciences and Nutrition, 49, 225-235. 